\title{
An Evaluation on Stakeholder's Preparedness on Transition to the Community for Learners with Autism after Graduation in Thika West, Kiambu County- Kenya
}

\author{
Onunga Dolly Anne
}

Mount Kenya University annedolly@ymail.com

\author{
Doi:10.5901/jesr.2014.v4n1p479
}

\section{Abstract}

\begin{abstract}
Education is believed to be the major tool for enhancing a country's development. Undoubtedly, it is the aim of most societies to provide equal opportunity and facilities to all school age children to gain access into the school system. Equalizing education opportunity has now become a primary stated goal to most countries (UN project, 2005) but children with special needs especially those with autism still have problems. What role do the headteachers, teachers, parents, community and other stakeholders play to make them fully benefit from the school programme? The role of the headteacher who is trained in special needs education impacts greatly on the improvement in the teaching and learning for children with autism. Though a lot of it whether they should be in school or not rest with their parents and teacher counselors depending on the information these counselors and the headteachers pass to the parents. It is also very important that more teachers are trained as special needs teachers. This will enhance more enrolment of autistic children in schools. What role does the community play in the education of children with special needs? There is general feeling that parents, the community and the children can improve a lot when there are frequent forums for sensitization. Regular "barazas" should also be held which are organized by chiefs or at the county level. This is prompting the project manager to want to establish how the headteachers, teachers, parents community, educationists Non- Governmental organizations and other stakeholders are ready to improve the education of children with autism.
\end{abstract}

Keywords: Autism, Learners, Special Needs, Education, Headteachers, Disability

\section{Conceptualizing Autism}

Autism is a lifelong developmental disability that affects how a person communicates with and relate to other people. It also affects how they make sense of the world around them. It is a spectrum condition, which means that, while all people with autism share certain difficulties, their condition will affect them in different ways. The characteristic behaviours of autism spectrum disorders may or may not be apparent in infancy (18-24 months), but usually become obvious during early childhood (24 months to 6 years).

\subsection{Early Childhood Signs}

- Does not babble or coo by 12 months.

- Does not gesture (point, wave, grasp) by 12 months.

- Does not say single words by 16 months.

- Does not say two- word phrases on his or her own by 24 months.

- Has any loss of any language or social skill at any age.

\subsection{Other indications}

- Lack of eye contact

- Lack of language of any verbalization

- Chronic infections

- Resistance to human interactions

- Hand biting, finger licking and hand flipping

- Teeth grinding 
- Unaware of his/ her environment and people in it.

Source: Ministry of Education- Educational Assessment and Referral Centre (EARC)-U-Shop Centre Thika West.

\subsection{A Logical Framework on Stakeholders Preparedness on Transition of Learners with Autism Back to the Community after Graduation in Kiambu County}

\begin{tabular}{|c|c|c|c|}
\hline Narrative Summary & Performance Indicators & Means Of Verification & Critical Assumption \\
\hline $\begin{array}{l}\text { GOAL } \\
\text { Stake holders to be fully prepared to } \\
\text { absorb persons with autism in the } \\
\text { community after graduation }\end{array}$ & $\begin{array}{l}\text { - Number of trained } \\
\text { workmanship } \\
\text { - Number of sheltered } \\
\text { workshops } \\
\text { - Number of vocational centres } \\
\text { - Number of social halls } \\
\text { - Amount of loan secured }\end{array}$ & $\begin{array}{l}\text { - End of term evaluation } \\
\text { - Discussion with } \\
\text { stakeholders } \\
\text { - Reports of successful self } \\
\text { employed persons with } \\
\text { autism } \\
\text { - Records from businesses } \\
\text { maintained by persons } \\
\text { with autism }\end{array}$ & $\begin{array}{l}\text {-Funds from government } \\
\text { agencies will be available } \\
\text { all on time } \\
\text {-Social political } \\
\text { environment will remain } \\
\text { favourable. } \\
\text {-Market will be available. } \\
\text {-Community members will } \\
\text { embrace the idea. }\end{array}$ \\
\hline $\begin{array}{l}\text { OBJECTIVE } \\
\text { Stakeholders to be fully prepared to } \\
\text { absorb persons with autism in the } \\
\text { community after graduation. }\end{array}$ & $\begin{array}{l}\text { - Degree of awareness about } \\
\text { partnering with persons with } \\
\text { autism } \\
\text { - Government policy on } \\
\text { transition o persons with } \\
\text { autism in the community } \\
\text { implemented } \\
\text { - Number of persons with } \\
\text { autism absorbed in the } \\
\text { project increases } \\
\text { - Level of production } \\
\text { increases }\end{array}$ & $\begin{array}{l}\text { - Reports on partnership } \\
\text { with autism with } \\
\text { members of the } \\
\text { community. } \\
\text { - Receipts from sales of } \\
\text { produced goods and } \\
\text { commodities. }\end{array}$ & $\begin{array}{l}\text { - Funds from the } \\
\text { government agencies will } \\
\text { be available and on time. } \\
\text { - Social political } \\
\text { environment will remain } \\
\text { favourable } \\
\text { - Market will be available } \\
\text { - Community members will } \\
\text { embrace the idea. }\end{array}$ \\
\hline $\begin{array}{l}\text { OBJECTIVE } \\
\text { Component } 1 \\
\text { Formulate awareness campaign } \\
\text { strategies and its implementation by } \\
\text { December } 2014\end{array}$ & $\begin{array}{l}\text { - Members of the community } \\
\text { and persons with autism } \\
\text { partnering in enterprise } \\
\text { increases } \\
\text { - Sale of products increase } \\
\text { - Number of partnerships } \\
\text { recorded increase }\end{array}$ & $\begin{array}{l}\text { - Interviews } \\
\text { - Receipts from sales } \\
\text { - Participants certificates } \\
\text { - Project reports }\end{array}$ & $\begin{array}{l}\text { - Funds will be available } \\
\text { and on time } \\
\text { - Political environment will } \\
\text { be favourable. } \\
\text { - All programs will run as } \\
\text { scheduled with no } \\
\text { interruptions } \\
\text { - Community member will } \\
\text { embrace it }\end{array}$ \\
\hline $\begin{array}{l}\text { Component } 2 \\
\text { Training needs of craftsmen and } \\
\text { amount allocated for purchases of } \\
\text { assets, equipment and other facilities } \\
\text { identified and allocated by } 2016\end{array}$ & $\begin{array}{l}\text { - Loan facilities increase } \\
\text { - Number of trained craftsmen } \\
\text { increase } \\
\text { - Facilities and equipment } \\
\text { needed by persons with } \\
\text { autism increase. } \\
\text { - Area to build facilities for } \\
\text { persons with autism } \\
\text { allocated }\end{array}$ & $\begin{array}{l}\text { - Availability of title deeds } \\
\text { - Receipts of equipment } \\
\text { and facilities purchased } \\
\text { - Records from micro } \\
\text { financial institutions on } \\
\text { loans acquired. }\end{array}$ & $\begin{array}{l}\text { - Funds will be available } \\
\text { on time } \\
\text { - Interventions will take } \\
\text { place as per } \\
\text { implementation } \\
\text { schedule. }\end{array}$ \\
\hline $\begin{array}{l}\text { Component } 3 \\
\text { Self-employment and self-reliance by } \\
\text { persons with autism realized by } 2017\end{array}$ & $\begin{array}{l}\text { - Number of self-employed } \\
\text { persons with autism will } \\
\text { increase } \\
\text { - Standards of living of persons } \\
\text { with autism improve } \\
\text { - Production from sheltered } \\
\text { workshops, social halls, } \\
\text { vocational centres increase }\end{array}$ & $\begin{array}{l}\text { - End of term evaluation } \\
\text { - Reports of successful } \\
\text { businesses of persons } \\
\text { with autism in the } \\
\text { community } \\
\text { - Annual reports of income } \\
\text { - Sales records from } \\
\text { vocational centres and } \\
\text { sheltered workshops }\end{array}$ & $\begin{array}{l}\text { - Markets will be available } \\
\text { - Lending institutions will } \\
\text { increase support } \\
\text { - Social-political } \\
\text { environment will remain } \\
\text { favourable }\end{array}$ \\
\hline $\begin{array}{l}\text { Component } 4 \\
\text { Project activities are systematically } \\
\text { monitored and evaluated }\end{array}$ & $\begin{array}{l}\text { - Number of progress and } \\
\text { evaluation reports produced } \\
\text { increase }\end{array}$ & $\begin{array}{l}\text { - Progress reports } \\
\text { - Evaluation reports }\end{array}$ & $\begin{array}{l}\text { - Funds will be available } \\
\text { and on time. } \\
\text { - Social political }\end{array}$ \\
\hline
\end{tabular}




\begin{tabular}{|l|l|l|l|}
\hline & & & $\begin{array}{l}\text { environment remain } \\
\text { favourable. }\end{array}$ \\
\hline $\begin{array}{l}\text { Activities needs } \\
\text { - Prepare a training } \\
\text { assessment Activity based indicators } \\
\text { - Activity based indicators } \\
\text { Develop awareness campaign } \\
\text { manuals Activity based indicators } \\
\text { - Striking partnership with donors and } \\
\text { NGOs } \\
\text { - Link the persons with autism to high } \\
\text { value markets }\end{array}$ & $\begin{array}{l}\text { - Activity based indicators } \\
\text { - Activity based indicators } \\
\text { - Activity based indicators } \\
\text { - Activity based indicators }\end{array}$ & $\begin{array}{l}\text { All funds are available } \\
\text { time }\end{array}$ \\
Upgrade marketing strategies & & & $\begin{array}{l}\text { Social-political } \\
\text { environment remain } \\
\text { favourable }\end{array}$ \\
\end{tabular}

1.4 A conceptual framework for stakeholders preparedness on transition of persons with autism to the community after grduation

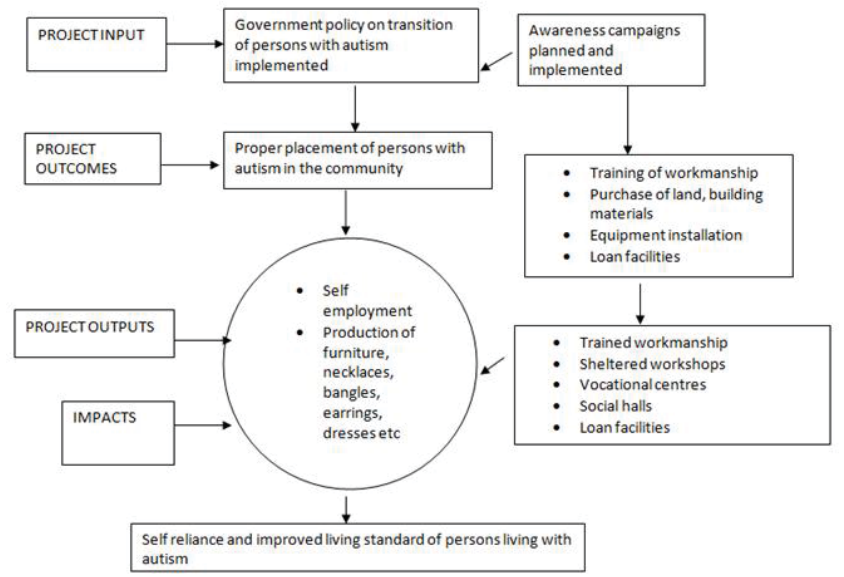

\subsection{Conceptual Framework for special schools with autism and special units}

\begin{tabular}{|c|c|c|c|c|c|}
\hline \begin{tabular}{|l} 
Professional \\
Experience of \\
the staff \\
Adminibtrative \\
support staff \\
Donorfunding \\
support
\end{tabular} & $\longrightarrow$ & $\begin{array}{l}\text { Planning and } \\
\text { management } \\
\text { Curriculum } \\
\text { Development } \\
\text { Training } \\
\text { Evaluation }\end{array}$ & $\begin{array}{l}\text { Countryand } \\
\text { zonal plans } \\
\text { Curriculum and } \\
\text { material } \\
\text { development } \\
\text { school } \\
\text { officials/Teache } \\
\text { i \& personnel } \\
\text { trained } \\
\text { Baseline survey } \\
\text { conducted } \\
\text { Formative } \\
\text { Evaluation } \\
\text { conducted }\end{array}$ & $\begin{array}{l}\text { Planning and } \\
\text { management } \\
\text { competence } \\
\text { Curnculum } \\
\text { materias/ } \\
\text { relevant and } \\
\text { suitable to } \\
\text { children'sneeds } \\
\text { Knowledge skills } \\
\text { and attitudes } \\
\text { improved }\end{array}$ & $\begin{array}{l}\text { - skills } \\
\text { achieved } \\
\text { - Academic } \\
\text { performance } \\
\text { improved } \\
\text { - Lfeskaks } \\
\text { improved } \\
\text { - Future hope } \\
\text { paramount }\end{array}$ \\
\hline
\end{tabular}

\section{Methodical Approach}

This study uses a descriptive survey. A descriptive survey research is a method of eliciting possible antecedents of events which have happened and cannot be engineered or manipulated by the investigator. Kerlinger (1967) defines the descriptive survey design as a systematic empirical inquiry in which a scientist does not have direct control of independent variables because their manifestations have already occurred or inherently not manipulated. Inferences about relations among variables are made without concomitant variations of independent and dependent variables. This study fits with in the ex-post facto design in that variable like physical facilities, learning and human resources other 
school related factors which affect persons with autism education is not easy to be manipulated.

Structured questionnaires developed by the researcher were utilized to obtain information from headteachers, teachers, interview schedules were conducted among parents, committee members and the county education officer. The computation of Pearson correlation co-efficient ( $r$ ) between scores of the two halves of the test was employed as shown by the formula.

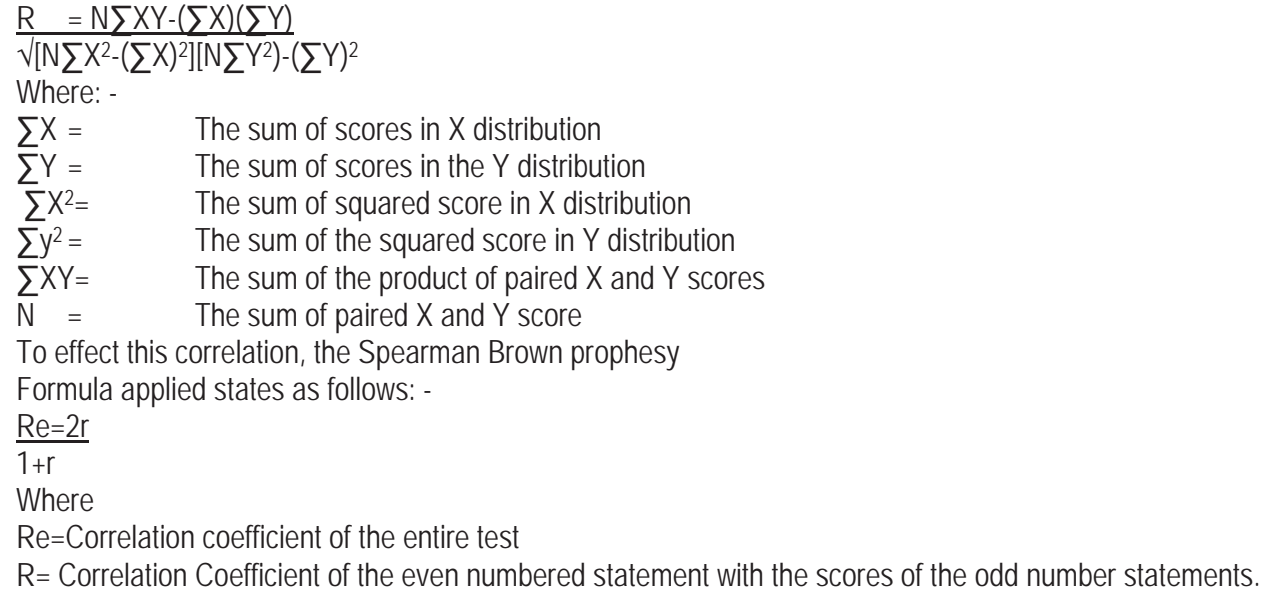

\section{Literature Review}

\subsection{Autism}

Autism is known as a complex developmental disability. Experts believe that autism presents itself during the first three years of a person's life. The condition is a result of a neurological disorder that has an effect on normal brain function, affecting developmental of the persons communication and social interaction skills (Tony Williams, 2010).

Autism Spectrum Disorder (ASD) can sometimes be referred to as Autistic Spectrum Disorder. ASDs are any developmental disabilities that have been cause by a brain abnormality. A person with an Autism Spectrum Disorder (ASD) typically has difficulty with social and communication skills (Tony Williams, 2010). He goes ahead to say that a person with ASD will typically also prefer to stick to a set of behaviours and will resist any major (and many minor) changes to daily activities. Several relatives and friends of people with ASDs have commented that if the person knows a change is coming in advance and has time to prepare for it; the resistance to change is either gone completely or is much lower.

\subsection{Social Skills}

The way in which a person with Autism Spectrum Disorder interacts with another individual is quite different compared to how the rest of the population behaves. If the symptoms are not severe, the person with ASD may be seen socially clumsy, sometimes offensive in his/her comments, or out of synch with everyone else. If the symptoms are mores severe, the person may be seen not to be interested in other people at all (Bill \& Brown, 2009). They go ahead and say that it is common for relatives, friends and people who interact with someone with an ASD sufferer makes very little eye contact. However, as health care professionals, teachers and others are improving their ability to detect signs of autism at an earlier age than before, eye contact among people with autism is improving. In many cases, if the symptoms are not severe, the person can be taught that eye contact is important for most people and he/she should remember look people in the eye.

Jefferson (2007) says that a person with autism may often miss the cues people give each other when they want to catch somebody's attention. The person with ASD might not know that somebody is trying to talk to them. They may also be very interested in talking to a particular person or group of people, but does not have the same skills as others to become fully involved. To put it more simply, they lack the necessary playing and talking skills, and for this reason they miss what to do after they graduate from their various institutions. 


\subsection{Empathy-Understanding and being aware of the feelings of others}

Sserugo (2010), says that a person with autism will find it much harder to understand the feelings of other people. His/her ability to instinctively empathize with others is much weaker than other people's. However, if they are frequently reminded of this, the ability to make other people's feelings into account improves tremendously. In some cases as a result of frequent practice, empathy does improve and some of it becomes natural rather than intellectual. Even so, empathy never comes as naturally for a person with autism as it does to others.

Wainaina,S.K (2011), says that having a conversation with a person with autism may feel very much like a one way trip. The person with ASD might give the impression that he/she may love a theme and talk about it a lot. However there is much less exchanging of ideas, thoughts and feelings than there might be in a conversation with a person who does not have autism. Almost everybody on this planet prefers to talk about him or herself more than other people; it is human nature. The person with autism usually does that even more (Jimmy \& Grace, 2010).

\subsection{Physical Contact}

Brown \& Junior (2009) say that a number of children with Autism Spectrum Disorder (ASD) do not like cuddling or being touched like other children do. It is wrong to say that all children with autism are like that. Many will hug a relative- usually the mother, father, grandmother, grandfather, teacher and other siblings- and enjoy it greatly. Often it is a question practice and anticipating that physical contact is going to happen. For example, if a child suddenly tickles another child's feet, he will most likely giggle and become exited and happy. If that child were to tickle the feet of a child with autism, without that child anticipating the contact, the result might be completely different. It is therefore important to look for ways of exciting them. They can be motivated and perform better in academic or in vocational activities.

\subsection{Loud noise, some smell and lights}

Mc George (2006) says that a person with autism usually finds sudden loud noises unpleasant and quite shocking. The same can happen with some smells and sudden changes in the intensity of lighting and ambient temperature. Many believe it is not so much more the actual noise, smell or light, but rather the surprise, and not being able to prepare for itsimilar to the response to surprising physical contact. If the person with autism knows something is going to happen he/ she can cope with it much better. Even knowing that something 'might' happen, and being reminded of it, helps a lot. They do not like things which surprise them.

\subsection{Speech}

Mc Owade (2012), concludes that the higher the severity of the autism, the more affected are a persons speaking skills. Many children with an autism spectrum disorder do not speak at all. People with autism will always repeat words or phrases they hear-an event called echolalia. The speech of a person with ASD may sound much more formal and woody, compared to other people's speech. Teenagers with Asperger's Syndrome can sometimes sound like young professors. Their intonation may sound flat.

\subsection{Repetitive Behaviours}

Mc Owade and Ralf (2012) say that a person with autism likes predictability. Routine is his/ her best friend. Going the motions again and again is very much part of his/ her life. To others, these very repetitive behaviours may seem like bizarre rites. The repetitive behavior might be a simple hop-skip-jump from one end of the room to the other, repeated again and again, page after page.

Brown(2007) says that people without autism are much more adaptable to changes in procedure. A child without autism may be quite happy to first have a bath, then brush his teeth and then put on his pyjamas before going to bed even though he usually brushes his teeth first. For a child with autism this change, bath first and then teeth, could completely put him/ her out, and may become very upset. Some people believe that helping a child with autism learn how to cope better with change is a good thing however forcing them to accept change like others could adversely affect their quality of life. 


\subsection{A child's development}

While children without autism will develop in many areas at a relatively harmonious rate, this may be the case for a child with autism. His/ her cognitive skills may develop fast, while other social and language skills trail behind. On the other hand his/her language skills may develop rapidly while their motor skills do not. They may not be able to catch a ball as well as the other children, but could have a much larger vocabulary. Nevertheless, the social skills of a person with autism will not develop at the same pace as other people's (Lauriane, 2010).

For a child with autism, learning may be unpredictable. They may learn something much faster than other children, such as how to read long words only to forget them completely later on. They may learn how to do something the hard way before they learn how to do it the easy way.

\subsection{Physical tics and Stimming}

Stafford (2010) discovers that it is not uncommon for people with autism to have tics. These are usually physical movements that can be jerky. Some ticks can be quite complicated can go on for a very long time. A number of people with autism are able to control when they happen, others are not. People with ASD who do have tics often say that they have to be expressed, otherwise the urge does not stop. For many going through the tics is enjoyable, and they have a preferred spot where they do them-usually somewhere private \& spacious. When parents first see this tics, especially the convoluted ones, they may experience shock \& worry.

\subsection{Myths about autism}

Smith and Bridgid (2008) say that a person with autism feels love, happiness, sadness and pain just like everybody else. Just because some of them may not express their feelings in the same way others do, does not mean at all that they do not have feelings-THEY DO!! It is crucial that the myth autistic people have no feelings - is destroyed. The myth is a result of ignorance, not some conspiracy. Therefore it is important that people who carry this myth in a helpful and informative way.

Not all people with autism have incredible gift or savantism for numbers or music. However, a sizeable proportion of people with an ASD (Autism Spectrum Disorder) have high IQs and a unique talent for computer science. German software company SAP AG has become aware of this and announced in may 2013 that it planned to employ hundreds of people with autism as software testers, programmers and data quality assurance specialists. There should be some arrangement for the same to take place in Africa.

\subsection{The benefits of early intervention for kids with ASD}

Huffs (2012), says that children with an ASD who receive early intervention tend to have better brain function, communication skills and overall social behaviour compared to ASD children with no early intervention. This was also reported by researchers from Yale School of Medicine in the journal of Autism and Developmental Disorder (ADD) (November 2012).

They add that the brain of kids with autism appear to respond well to "pivotal response treatment" if it is provided early on. The program, which requires parental involvement as well as "play" situations, was created specifically for children with autism. The new technique incorporates learning and developmental factors which are easy to use with very young children.

\subsection{Closing in on gene mutations linked to autism}

The researchers Grein and Horde (2012) say that a mutation in the gene that encodes a protein, Syn GAPI, severely disrupts how the developing brain circuits organize themselves during a human's first years of life. Researchers from the Scripps Research Institute reported in the journal Cell (November 2012 issue) that they are discovering how genetic mutations can be responsible for the behavioural and cognitive problems found in people with ASD.Syn GAPI is estimated to cause disabilities in about 1 million people around the world. It is known to be directly involved in raising autism risk.

The authors explain that genetic mutations that cause ASDs generally affect synapses. A significant proportion of 
children with severe behavioural and intellectual impairments are believed to carry singly mutations in key neurodevelopmental genes. Head researcher, professor Gavin Rumbaugh, Says "in this study, we did something no one else had done before. Using an animal model, we looked at mutation known to cause intellectual disability and showed for the first time a causative link between abnormal synapse maturation during brain developmental and life-long cognitive disruptions commonly seen in adults with a neurodevelopmental disorder. There are a few genes that can't be altered without affecting normal cognitive abilities. SynGapi is one of the most important genes in cognition- so far every time a mutation that disrupts the function of SynGapi has been found, that individual's brain simply could not develop correctly. It regulates the development of synaptic function like no other gene I have seen."

\subsection{Flu and Persistent fever during pregnancy raise autism risk}

If a pregnant woman gets the flu or has a fever that persists for more than one week, there is a greater chance that her offspring will be diagnosed with an ASD by the age of three years, researchers from the university of Aarhus, Denmark, reported in the journal Pediatrics (November, 12 ${ }^{\text {th }}, 2012$ issue).

The scientists examined data on 96,736 children in Denmark from 1997 to 2003. They found that non- flu respiratory infections, urinary tract infections during pregnancy were not associated with a higher risk of autism for the baby.However, the following illnesses and circumstances did increase the risk of the child later on being diagnosed with an ASD:

- Influenza during pregnancy- doubles autism risk for the child

- Persistent fever during pregnancy- that lasted for at least one week triples autism risk

- Antibiotic usage during pregnancy- slightly raises autism risk for the child

Head researcher, Hjordis Osk Atladottir, MD, PhD, emphasizes that autism risk for pregnant mothers who catch the flu or those with a persistent fever should not be alarmed- $98 \%$ of thos e who did become ill in heir study went 0 to give birth to "healthy" babies who never developed an ASD.

\section{Recent research on links to autism risk}

Parents with bipolar disorder or schizophrenia- a child whose parent, brother or sister has been diagnosed with bipolar disorder or Schizophrenia has a higher risk of being diagnosed with an ASD, scientists form the University of North Carolina reported in archives of General Psychiatry (July 2012).

Older Fathers- If the father is older during conception, there is a greater risk of autism for the baby. Scientists explained in the journal nature that an older father has a greater chance of passing on new mutations to hiss babies than older mothers.

Immune System Irregularities- Caltech (California Institute of Technology) researchers reported that in PNAS (Proceedings of the National Academy of Sciences) (July 2012) that certain changes in an overactive immune system can contribute to autism-like behaviours in mice. In some cases, this activation may be related to how the fetus develops while in the womb.

Scientific Gene Mutations- Scientists from the Seattle Children's research institute found new gene mutations which were linked to the development of autism, epilepsy, hydrocephalus and cancer. The mutations in the following genes- AKT3, PIK3R2 and PIK3CA. Their study was published in Nature Genetics (July 2012).

Air traffic pollution during pregnancy and autism link- If a pregnant mother is exposed to air traffic pollution during her pregnancy, the risk of autism in her offspring is greater, researchers from university of Southern California and children's Hospital Los Angeles reported in archives of general psychiatry (November 2012 issue). The investigators wrote "Exposure to traffic - related air pollution, PM (Particulate matter) and nitrogen dioxide were associated with an increase in the risk of autism. These effects were observed using measures of air pollution with variation on both local and regional levels, suggesting the need for further study to understand both individual pollutant contributions and the effects of pollutant mixtures on disease.

\section{Data Analysis and Discussion}

Total number of participants were 22 teachers, 4 headteachers, 4 parents, 1 committee member and 1 county education officer.

Among the headteachers one was a graduate while 3 were diploma. Therefore graduate attracted $25 \%$ and non 
graduate $75 \%$. education:

Question 4 about headteachers who had special education. None of the headteachers had undergone special

In questionnaire for teachers

Q1. The parents were both males and females

Q2. Age 26 - 30 had 2 teachers

31 - 40 were 4 teachers

41 - 50 were 5 teachers

Above 50 were 11 teachers

Q3. Highest profession for teachers were as follows:-

PI 2 teachers

Diploma 10 teachers

Degree 6 teachers

Others 4teachers

Q4. The learners were graded according to their categories. Every teacher had his/her categories of learners and some had no classes of their own

Q5. In every school there were mild, moderate and severe learners.

Q6. Boys in all the schools were 90 while girls were 66 .

Q7. Equipment in terms of carpentry tools, sewing machines, arts and craft items are necessary.

Q8. They go back to the community and most of them languish in poverty.

Q1. On teachers' questionnaire

They were both males and females

Q2. Age $31-40$ were 14

41 - 50 were 6

Above 50 were 2

Q3. PI were 2 teachers

Diploma were 8 teachers

Others were 2 teachers

Q4. Special school for autism had 86 while units had a total of 70 learners.

Q5. Total learners in those schools were 156.

Q6. In the four schools, 90 were boys while 66 were girls.

Q7. Vocational centres are required to improve their lives.

Q8. They go to the community and some languish in poverty.

\subsection{Appendix III for the parents}

Q1. There are both males and females in the schools.

Q2. The parents who participated had both normal children and those with autism. Those with autism were 5 children and those without autism 13.

Q3. Mild were 2 and moderate 3 children.

Q4. Most parents talked of small businesses while others were for the vocational centres.

Q5. The answer for this number was yes with suggestions for the following:-

- Supply of equipment

- Provision of funds

\subsection{Index IV}

- Construction of training centres

Q1. They were both males and females.

Q2. They were twenty members.

Q3. Once every month or whenever need arises.

Q4. Yes they are.

Q5. Yes the community should be ready to receive them after graduation.

Q6. Vocational centres supported by support groups in the community 
Q7. The activities are many starting from gardening, recreation, fishing and others.

\subsection{County Education Officer}

Q1. Gender in this case was male.

Q2. There are 8 schools for learners with Autism.

Q3. In the four schools 14 teachers are special education teachers and 8 are not.

Q4. The Ministry is planning to build vocational centres and provide equipment and funds.

Q5. He visits them once every term but sends his officers more often.

Q6. There are four Educational Assessment and Resource centres (EARC).

\section{Conclusion}

According to the findings in the study if the strategies laid down are followed, there will be a very big percentage of success. Persons with Autism will be able to earn their living in an honourable way.

\section{References}

Abrahams BS, Geschwind DH (2008), Advances in Autism genetics: on the threshold of a neurobiology.

American Psychiatric Association. Diagnostic and statistical manual of mental disorders: Washington DC :American Psychiatric Association; (2008)

Caronna BS Milunsky JM,Tag er-Flusberg H.(2008)Autism spectrum disorders: clinical psychiatric

Filipek PA,Accardo PJ, Baranek GT et al (1999), The screening and diagnosis paediatric clinic North America.

Garber JS, (2009), Vaccines and autism: a tale of shifting hypotheses.

Geschwind DH. (2008), Autism many, common pathways.

Howlin P. Goode S., Hutton J., Rutter M. (2009). Adult outcome for children with autism spectrum

Levy SE, Mandell DS, Schultz RT. (2009). Autism Lancet..

National Health Statistics Report March (2013)

Rapin I, Tuchman RF. 2008. Autism: definition, neurobiology, screening, diagnosis.

Rogers SJ. (2009), What are infant siblings teaching us about autism infancy?

Silverman C, (2008), Fieldwork on another planet: Social Science Perspectives on the autism spectrum.

Stephen J. Blumberg, PhD, et al (2007), changes in Prevalence of Parent - reported Autism Spectrum Disorders.

World Health Organization (2009), Pervasive developmental disorders. 
